\title{
The 100 Top-Cited Studies About Pain and Depression
}

\author{
Liang Du ${ }^{1,2+}$, Shanxia $\mathrm{Luo}^{3+}$, Guina Liu ${ }^{4}$, Hao Wang ${ }^{4}$, Lingli Zheng ${ }^{3}$ and \\ Yonggang Zhang ${ }^{1,2 *}$
}

1 Department of Periodical Press and National Clinical Research Center for Geriatrics, West China Hospital, Sichuan University, Chengdu, China, ${ }^{2}$ Chinese Evidence-Based Medicine Center, West China Hospital, Sichuan University, Chengdu, China, ${ }^{3}$ Mental Health Center, West China Hospital, Sichuan University, Chengdu, China, ${ }^{4}$ West China School of Medicine, Sichuan University, Chengdu, China

OPEN ACCESS

Edited by:

Qing Zhao,

Second Affiliated Hospital of Guangzhou Medical University, China

Reviewed by:

Miao Qu,

Xuanwu Hospital, Capital Medical University, China Milena B. Cukic,

Amsterdam Health and Technology Institute (AHTI), Netherlands

*Correspondence: Yonggang Zhang jebm_zhang@yahoo.com

tThese authors have contributed equally to this work

Specialty section: This article was submitted to Emotion Science,

a section of the journal

Frontiers in Psychology

Received: 31 July 2019 Accepted: 27 December 2019 Published: 11 February 2020

Citation:

Du L, Luo S, Liu G, Wang H, Zheng L and Zhang Y (2020) The 100

Top-Cited Studies About Pain and Depression. Front. Psychol. 10:3072. doi: 10.3389/fpsyg.2019.03072
With the estimated high prevalence in the population, the two symptoms of pain and depression threaten the well-being of millions worldwide. Researches of the two symptoms increased year by year. Top-cited studies will help to understand the achievement and guide researchers toward the direction of the research field. However, it is unclear for researches in the field of pain and depression. In this paper, we reviewed the bibliometric characteristics of the top-cited papers about pain and depression. We will review the evidence of authorship, country of origin, institution, journal, study type, and publication year for the 100 top-cited studies on pain and depression based on the Web of Science Core collection. We also highlight studies with the highest cited times. Our study concluded that pain and depression were correlated, which may share common biological pathways.

Keywords: pain, depression, top-cited, bibliometric review, citation, citation analysis

\section{INTRODUCTION}

With the estimated prevalence in the adult population ranges from 5 to 60\% (Gureje et al., 1998; Blyth et al., 2001; Smith et al., 2001), the pain has become the most common problem worldwide. Likewise, depression, the first cause of disability before 2030 forecasted by WHO (2017), prevalence of which in primary care is estimated at 5-10\% (Katon and Schulberg, 1992). Current evidence suggests that pain and depression have reciprocal influence (Kroenke et al., 2011) and often co-occur (Kroenke et al., 2010). The prevalence of co-occurrence of pain and depression ranges from 30 to 65\% (Arnow et al., 2006; Bair et al., 2008), even higher than the respective prevalence of pain and depression (Bair et al., 2003). Growing number of studies investigated the comorbidity of pain and depression (Campbell et al., 2003; Chopra and Arora, 2014; Li, 2015), yet there is no relevant evidence in the aspect of bibliometrics analysis.

Bibliometric method has been widely used to provide an analysis of books and articles and has been used to assess the impact of research outputs (Blakeman, 2018). Citation analysis is one of the key methods of bibliometric method, aiming at constructing indicators of research performance from a quantitative analysis of scholarly documents (Moed, 2009). The frequency of citation indicates the relative significance in the particular discipline (Iyengar et al., 2009; Kanter, 2009). Analysis of top-cited studies helps understand the current achievement and guide researchers toward the direction of development of the field (Zhang et al., 2019a,b).

Analysis of top-cited articles has been used in different fields, including cancer immunotherapy (Zhang et al., 2019a), cardiology (Shuaib et al., 2015), gastroenterology and hepatology (Azer and Azer, 2016), and urology (Ipekci et al., 2017). However, there is no top-cited analysis of the comorbidity of pain and depression. Intend to bridge this gap, in this study, we performed a bibliometirc review to assess 100 top-cited studies on pain and depressions based 
on Web of Science Core Collection and discuss the relationship between pain and depression.

\section{REVIEW METHODS}

Studies of pain and depression published in journals were identified in the Web of Science Core Collection using the keywords "pain" and "depression" in July 2019. The Web of Science Core Collection database includes peer-reviewed publications indexed from more than 10,000 high impact journals in the world (Brown et al., 2019). All published papers since 1945 were searched in the database, and citation count ranked the results. Two researchers independently selected the 100 top-cited studies about pain and depression. Any article studied the comorbidity of pain and depression were included for further analysis. Articles mentioned pain and depression without investigating the relation between pain and depression were excluded. The disagreements were resolved by discussion. If necessary, the discrepancies were resolved by consulting the third researcher. A data extracted form was pre-defined, including the basic information, such as title, the first author and corresponding author's name, publication year, the number of citations, source of the journal, impact factor of the journal, article type, organization of corresponding author, country of origin based on the corresponding author. Each study was reviewed, and the information was collected. The relationships between the number of citations and journal, publication year, study type, country, institution, and authorship were analyzed. Descriptive statistics were used to present the results. The analyzed data and results could be assessed by contact with the corresponding author of this study. This is a bibliometric review, so ethics is not applicable.

\section{THE CITATION CHARACTERISTICS OF THE 100 TOP-CITED STUDIES ON PAIN AND DEPRESSION}

The 100 top-cited studies are listed in Table $\mathbf{1}$ in descending order of the number of citations, which were published from 1979 to 2014. The number of citations ranged from 94 to 1,576, and the mean citation number was 191 . The most frequently cited study was "Depression and pain comorbidity-a literature review" (Bair et al., 2003). It was published in Archives of Internal Medicine (now JAMA Internal Medicine), the author conducted a literature review to determine the prevalence of pain and depression, they also reviewed the effects of comorbidity on diagnosis, clinical outcomes, and treatment. The second most-cited paper was a review named "Chronic pain-associated depression: antecedent or consequence of chronic pain? a review" (Fishbain et al., 1997), which was published in Clinical Journal of Pain, it was cited by other studies about 618 times. The authors reviewed eighty-three studies and found that depression was more common in chronic pain patients (CPPs) than in healthy controls. The third most cited study was a review named "Chronic pain and depression-dose the evidence support a relationship" (Romano and Turner, 1985). It was published in Psychological Bulletin and been cited 523 times.

\section{JOURNALS OF TOP-CITED STUDIES}

Among the 100 top-cited studies, 20 were published in Pain, 6 from Clinical Journal of Pain, 5 from Psychosomatic Medicine, and 4 from Journal of Pain. 3 studies were published in each of the following journals: Jama-Journal of the American Medical Association, Journal of Abnormal Psychology, Journal of Pain and Symptom Management and Journal of Consulting and Clinical Psychology. The other journals had $<3$ studies. The total citation number of journals ranged from 94 to 3,508 . The impact factors of all the journals in 2018 were between 1.438 and 51.273 (Table 2).

\section{PUBLICATION YEARS OF 100 TOP-CITED STUDIES}

The 100 top-cited studies were published between 1979 and 2014 . The year 2003 and 2005 were the years with most citation number $(n=8)$, followed by $2008(n=7)$, and $2001(n=6), 2004(n=$ $6)$, and $2009(n=6)$. Of all the years, the year 2003 contributed the most citation times $(n=2,920)$.

\section{STUDY TYPES OF TOP-CITED STUDIES}

Among the 100 top-cited studies, 21 studies were reviews, of which 2 were systematic reviews (SR)/meta-analyses; 79 were articles, of which 73 were observational studies, 5 were randomized controlled trials and 1 was basic research.

\section{COUNTRIES OF THE TOP-CITED STUDIES}

According to the country of origin of authors, the top-cited studies were mostly conducted in the USA $(n=74)$, followed by Canada $(n=11)$, and Germany $(n=4)$. China, England, Italy and Netherlands contributed two studies each, while Australia, Denmark and France only contributed 1 study each.

\section{INSTITUTIONS PUBLISHED AT LEAST TWO OF THE TOP-CITED STUDIES}

In our review, we listed the institutions contributed more than 1 study. Indiana University from the USA produced the most cited studies $(n=8)$, followed by University of Washington ( $n$ =7). University of Pittsburgh and University of Michigan both contributed five studies. Johns Hopkins University produced four studies. The rest of the institutions contributed less than four studies. Of the top 16 institutions, 12 institutions were from the USA, and 14 were the university.

\section{AUTHORS PUBLISHED AT LEAST TWO PAPERS AS FIRST AUTHOR OR CORRESPONDING AUTHOR OF THE TOP-CITED STUDIES}

We also summarized the first authors or corresponding authors who published more than one studies of the 100 top-cited studies. 
TABLE 1 | The 100 top-cited studies in pain and depression.

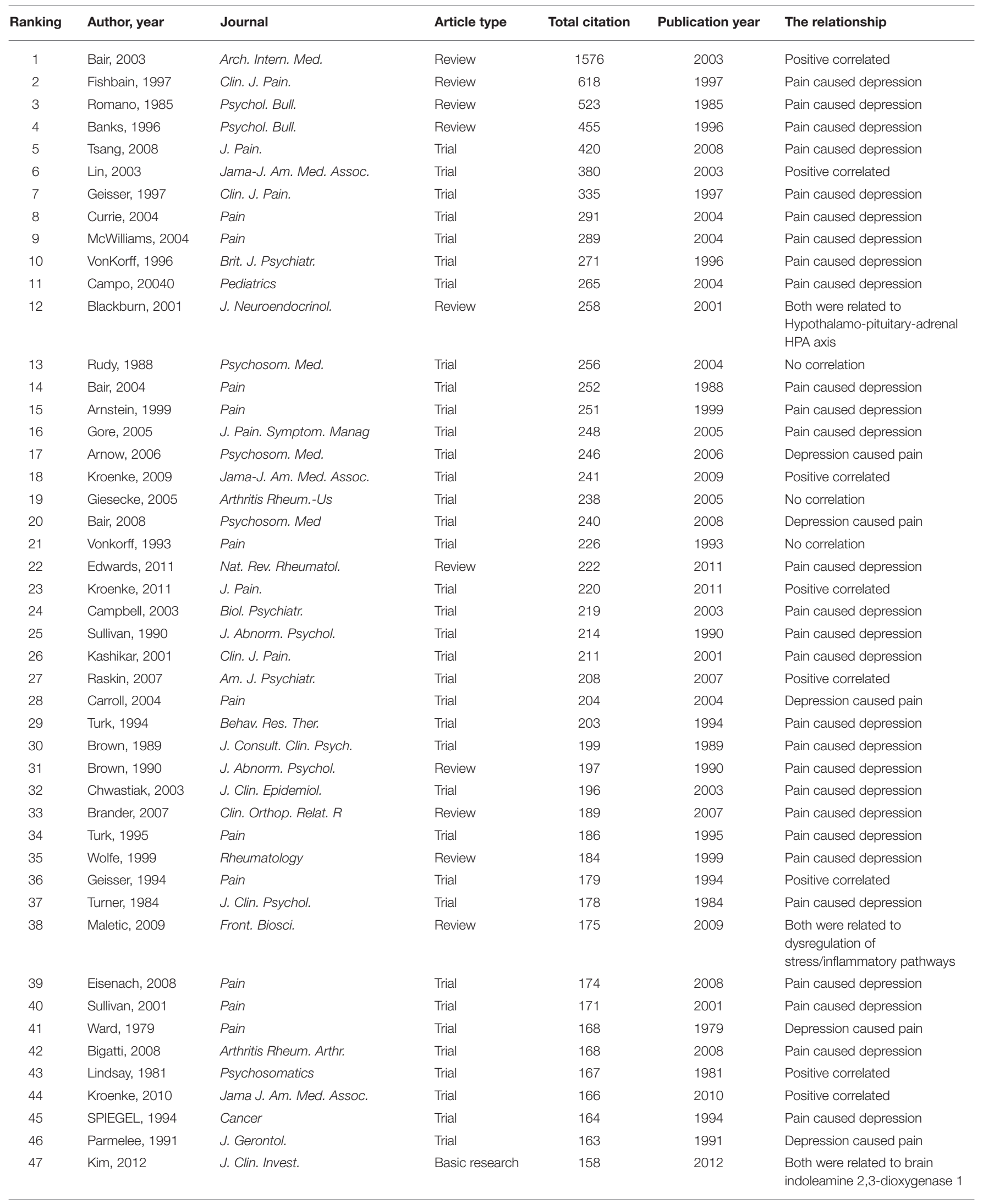


TABLE 1 | Continued

\begin{tabular}{|c|c|c|c|c|c|c|}
\hline Ranking & Author, year & Journal & Article type & Total citation & Publication year & The relationship \\
\hline 48 & $\begin{array}{l}\text { Haythornthwaite, } \\
1991\end{array}$ & Pain & Trial & 150 & 1991 & Positive correlated \\
\hline 50 & Wilson, 2002 & Clin. J. Pain & Trial & 145 & 2002 & Depression caused pain \\
\hline 51 & Diepenmaat, 2006 & Pediatrics & Trial & 145 & 2006 & Pain caused depression \\
\hline 54 & $\begin{array}{l}\text { Ciechanowski, } \\
2003\end{array}$ & Pain & Trial & 141 & 2003 & $\begin{array}{l}\text { Both were related to attachment } \\
\text { theory }\end{array}$ \\
\hline 55 & Mullen, 1987 & J. Rheumatol. & Trial & 141 & 1987 & $\begin{array}{l}\text { Both were related to } \\
\text { psychoeducation }\end{array}$ \\
\hline 56 & Suhr, 2003 & J. Psychosom. Res. & Trial & 141 & 2003 & Both were related to fibromyalgia \\
\hline 60 & Bar, 2005 & Pain & Trial & 139 & 2005 & $\begin{array}{l}\text { Depression caused lateralized } \\
\text { perception of pain }\end{array}$ \\
\hline 61 & Lepine, 2004 & Hum. Psychopharm. Clin. & Trial & 138 & 2004 & Pain caused depression \\
\hline 62 & Miller, 2009 & J. Pain & Trial & 134 & 2009 & Pain caused depression \\
\hline 63 & Kelsen, 1995 & J. Clin. Oncol. & Trial & 134 & 1995 & $\begin{array}{l}\text { Both were not related to recently } \\
\text { diagnosed adenocarcinoma of } \\
\text { the pancreas }\end{array}$ \\
\hline 64 & Hassett, 2000 & Arthritis Rheum. Us & Trial & 132 & 2000 & Both were related to fibromyalgia \\
\hline 65 & Ciaramella, 2001 & Psycho-Oncology & Trial & 132 & 2001 & Depression caused pain \\
\hline 66 & $\begin{array}{l}\text { Lautenbacher, } \\
1999\end{array}$ & Psychosom. Med. & Trial & 129 & 1999 & $\begin{array}{l}\text { Depression elevated pain } \\
\text { perception threshold }\end{array}$ \\
\hline 73 & Keefe, 1986 & J. Consult Clin. Psych. & Trial & 116 & 1986 & Depression caused pain \\
\hline 74 & Braden, 2009 & Gen Hosp. Psychiatr. & Trial & 115 & 2009 & $\begin{array}{l}\text { Depression increased use of } \\
\text { opioid therapy for non-cancer } \\
\text { pain }\end{array}$ \\
\hline 75 & Klauenberg, 2008 & Pain & Trial & 115 & 2008 & $\begin{array}{l}\text { Depression reduced pain } \\
\text { perception threshold }\end{array}$ \\
\hline 76 & Turner, 2005 & J. Pain & Trial & 114 & 2005 & $\begin{array}{l}\text { Self-efficacy for managing pain } \\
\text { decreased depression }\end{array}$ \\
\hline 77 & Sharpe, 2001 & J. Psychosom. Res. & Trial & 113 & 2001 & Pain caused depression \\
\hline 78 & Chiu, 2005 & Pain & Trial & 113 & 2005 & $\begin{array}{l}\text { Depression reduced pain } \\
\text { perception threshold }\end{array}$ \\
\hline 79 & Auerbach, 2001 & J. Oral Maxil Surg. & Trial & 112 & 2001 & Pain caused depression \\
\hline 80 & Davison, 2005 & J. Pain Symptom. Manage. & Trial & 111 & 2005 & Pain caused depression \\
\hline 81 & Gaston, 1999 & Cancer Pract. & Trial & 111 & 1999 & Positive correlated \\
\hline 82 & Brown, 2010 & Psycho-Oncology & Trial & 111 & 2010 & Positive correlated \\
\hline 83 & MAGNI, 1987 & Pain & Review & 110 & 1987 & Positive correlated \\
\hline 84 & Geerlings, 2002 & Soc. Psych. Psych. Epid. & Trial & 107 & 2002 & Positive correlated \\
\hline 85 & Coenen, 2011 & Neurosci. Biobehav. R & Review & 107 & 2011 & Positive correlated \\
\hline 86 & Jann, 2007 & Pharmacotherapy & Review & 107 & 2007 & Both reduced by antidepressant \\
\hline 87 & Munce, 2007 & Psychosomatics & Trial & 105 & 2007 & Pain caused depression \\
\hline
\end{tabular}


TABLE 1 | Continued

\begin{tabular}{|c|c|c|c|c|c|c|}
\hline Ranking & Author, year & Journal & Article type & Total citation & Publication year & The relationship \\
\hline 88 & Blumer, 1982 & J. Nerv. Ment. Dis. & Trial & 104 & 1982 & Depression caused pain \\
\hline 89 & Illi, 2012 & Cytokine & Trial & 103 & 2012 & Positive correlated \\
\hline 90 & Haley, 1985 & Pain & Trial & 101 & 1985 & Pain caused depression \\
\hline 91 & Kroenke, 2008 & Pain & Trial & 101 & 2008 & Positive correlated \\
\hline 92 & Means, 2008 & Depress Anxiety & Trial & 100 & 2008 & Positive correlated \\
\hline 93 & Wolfe, 2009 & Arthritis Rheum-Arthr. & Trial & 100 & 2009 & Pain caused depression \\
\hline 94 & Kerns, 1988 & J. Consult. Clin. Psych. & Trial & 99 & 1988 & Pain caused depression \\
\hline 95 & O’Mahony, 2005 & J. Pain. Symptom. Manage. & Trial & 99 & 2005 & Pain caused depression \\
\hline 96 & Foley, 2007 & Am. J. Geriat. Psychiatr. & Trial & 96 & 2007 & Positive correlated \\
\hline 97 & Hendeler, 1984 & J. Clin. Psychiatr. & Trial & 96 & 1984 & Pain caused depression \\
\hline 98 & Geisser, 2000 & Clin. J. Pain & Trial & 95 & 2000 & Pain caused depression \\
\hline 99 & Schwartz, 2014 & Science & Basic research & 95 & 2014 & Pain caused depression \\
\hline 100 & Finan, 2013 & Sleep. Med. Rev. & Review & 94 & 2013 & Both related to Dopamin \\
\hline
\end{tabular}

Reference details are provided in Supplementary Data Sheet 1.

Among the nine first authors and ten corresponding authors, Kroenke, $\mathrm{K}$ published the highest number of papers as both the first author $(n=4)$ and corresponding author $(n=4)$.

\section{DISCUSSION}

With the growing awareness of the link between pain and depression, an increasing number of literatures have focused on the interaction between these two conditions. Although literature reviews of the comorbidity of pain and depression have been conducted (Fishbain et al., 1997; Bair et al., 2003; Gagliese et al., 2007), no bibliometrics study to describe the current situation and trend of this field yet, thus we performed the current review to assess it. This study aimed to review the development and progress of the relationship between pain and depression by identifying the top-cited studies in this field.

The 100 top-cited studies were cited from 94 to 1576 times, published in 52 different journals between 1976 and 2014. As it shown that the number of citations is rising as time goes by, of the 100 top-cited articles, 81 were published 10 years ago. Although, the oldest article may not be the most significant research in this field. Probably because the authors tend to cite the articles which were cited in the papers instead of reading and citing the original articles. Pain, with 20 of the 100 top-cited studies, received the highest number of citations of 3,508 times. Of the top 5 most cited journals, three journals featuring the spectrum of pain research, which indicated that studies published in professional journals might attract more attention and achieve higher academic value.

Although the studies of pain and depression have been done worldwide, $74 \%$ of the top-cited studies were originated from academic institutions in the USA. The most influential institution was the Indiana University, with eight top-cited articles published from 1984 to 2009. The significant influence of the USA may be attributed to its large number of scientific research institutions and the abundant research funds. Also, there may be some bias in this finding. On one hand, consideration of the subtle connection between pain and depression maybe more focused by developed countries than developing countries. On the other hand, researchers from unknown labs in developing countries are less influential in the field who may not have access or resources to publish articles in renowned journals.

Of all the first author and corresponding author, Kroenke, $\mathrm{K}$ contributed most of the top-cited articles, and 2 of the four papers were published in JAMA. In addition to the four studies, he also made contributions in other five papers of the top-cited articles. Dr. Kroenke is an internationally respected expert in physical and psychological symptoms, whose principal research interests include pain and depression, and has made a great contribution to this research field. A study concluded a phenomenon that once in control of the commanding heights of their fields, star scientists tend to hold on to their exalted position for a long time, and a burst of published research after the "star" in that field dies (Azoulay et al., 2019). This phenomenon may indicate that big names in science are in a way suppressing younger colleagues work.

The most highly cited articles in pain and depression were in the field of clinical trials, of which $94 \%$ were observational study. Pain and depression are the most common physical and psychological symptom-based conditions (Kroenke et al., 2011), respectively, which based on an individual's subjective feelings. Measurement of pain and depression according to the scores of scales. For these reasons, most of the studies were observational studies instead of basic study.

Studies showed that $65 \%$ of depressive patients complained about one or more pain, while $5-85 \%$ patients with pain reported depression (Bair et al., 2003; Lepine and Briley, 2004; Miller and Cano, 2009). As presented in Table 1, the relationship between pain and depression were investigated in the 100 papers. Forty seven of the 100 top-cited articles indicated that pain caused depression, 23 papers mentioned they were corelated, 9 papers revealed that depression caused pain, while 3 studies found no significant correlation between pain and depression. Five articles investigated the possible common mechanisms of these two 
TABLE 2 | Journals of the 100 top-cited studies published.

\begin{tabular}{|c|c|c|c|c|}
\hline Journal & $\begin{array}{c}\text { Number of } \\
\text { studies }\end{array}$ & $\begin{array}{l}\text { Total } \\
\text { citation }\end{array}$ & $\begin{array}{l}\text { Average } \\
\text { citation }\end{array}$ & $\begin{array}{c}\text { Impact } \\
\text { factor (2018) }\end{array}$ \\
\hline Pain & 20 & 3508 & 175 & 6.029 \\
\hline JAMA Intern. Med. & 1 & 1576 & 1576 & 20.768 \\
\hline Clin. J. Pain & 6 & 1549 & 258 & 2.893 \\
\hline Psychosom. Med. & 5 & 1010 & 202 & 3.937 \\
\hline Psychol. Bull. & 2 & 978 & 489 & 16.405 \\
\hline J. Pain & 4 & 888 & 222 & 2.236 \\
\hline $\begin{array}{l}\text { JAMA J. Am. Med. } \\
\text { Assoc. }\end{array}$ & 3 & 787 & 262 & 51.273 \\
\hline J. Abnorm. Psychol. & 3 & 551 & 184 & 5.519 \\
\hline $\begin{array}{l}\text { J. Pain. Symptom } \\
\text { Manag. }\end{array}$ & 3 & 458 & 153 & 3.378 \\
\hline J. Consult. Clin. Psych. & 3 & 414 & 138 & 4.358 \\
\hline Pediatrics & 2 & 410 & 205 & 5.401 \\
\hline Arthritis Rheum. Arthr. & 2 & 370 & 185 & 9.002 \\
\hline J. Gerontol. & 2 & 285 & 143 & 3.418 \\
\hline Psychosomatics & 2 & 272 & 136 & 1.541 \\
\hline Brit. J. Psychiatr. & 1 & 271 & 271 & 7.233 \\
\hline Arthritis Care. Res. & 2 & 268 & 134 & 4.530 \\
\hline J. Neuroendocrinol. & 1 & 258 & 258 & 3.040 \\
\hline J. Psychosom. Res. & 2 & 254 & 127 & 2.722 \\
\hline Psycho-Oncology & 2 & 243 & 122 & 3.430 \\
\hline J. Clin. Psychiatr. & 2 & 235 & 118 & 4.023 \\
\hline Nat. Rev. Rheumatol. & 1 & 222 & 222 & 18.545 \\
\hline Biol. Psychiatr. & 1 & 219 & 219 & 11.501 \\
\hline Am. J. Psychiatr. & 1 & 208 & 208 & 13.655 \\
\hline Behav. Res. Ther. & 1 & 203 & 203 & 4.309 \\
\hline J. Clin. Epidemiol. & 1 & 196 & 196 & 4.650 \\
\hline Clin. Orthop. Relat. $R$ & 1 & 189 & 189 & 4.154 \\
\hline Rheumatology & 1 & 184 & 184 & 5.149 \\
\hline J. Clin. Psychol. & 1 & 178 & 178 & 2.059 \\
\hline Front. Biosci. & 1 & 175 & 175 & 2.214 \\
\hline Cancer & 1 & 164 & 164 & 6.102 \\
\hline J. Clin. Invest. & 1 & 158 & 158 & 12.282 \\
\hline Pharmacol. Rev. & 1 & 143 & 143 & 18.886 \\
\hline J. Rheumatol. & 1 & 141 & 141 & 3.634 \\
\hline $\begin{array}{l}\text { Hum. Psychopharm. } \\
\text { Clin. }\end{array}$ & 1 & 138 & 138 & 2.265 \\
\hline J. Clin. Oncol. & 1 & 134 & 134 & 28.245 \\
\hline Pain Med. & 1 & 128 & 128 & 2.758 \\
\hline Oncol. Nurs. Forum. & 1 & 126 & 126 & 1.438 \\
\hline $\begin{array}{l}\text { Arch. Phys. Med. } \\
\text { Rehab. }\end{array}$ & 1 & 125 & 125 & 2.697 \\
\hline Arthritis Rheum-Us & 1 & 118 & 118 & 4.530 \\
\hline J. Prosthet. Dent. & 1 & 118 & 118 & 2.787 \\
\hline Gen. Hosp. Psychiatr. & 1 & 115 & 115 & 3.220 \\
\hline J. Oral. Maxil. Surg. & 1 & 112 & 112 & 1.781 \\
\hline Cancer. Pract. & 1 & 111 & 111 & $1.553^{\star}$ \\
\hline Neurosci. Biobehav. $R$ & 1 & 107 & 107 & 8.002 \\
\hline Pharmacotherapy & 1 & 107 & 107 & 3.045 \\
\hline $\begin{array}{l}\text { Soc. Psych. Psych. } \\
\text { Epid. }\end{array}$ & 1 & 107 & 107 & 3.152 \\
\hline
\end{tabular}

(Continued)
TABLE 2 | Continued

\begin{tabular}{lcccc}
\hline Journal & $\begin{array}{c}\text { Number of } \\
\text { studies }\end{array}$ & $\begin{array}{c}\text { Total } \\
\text { citation }\end{array}$ & $\begin{array}{c}\text { Average } \\
\text { citation }\end{array}$ & $\begin{array}{c}\text { Impact } \\
\text { factor (2018) }\end{array}$ \\
\hline J. Nerv. Ment. Dis. & 1 & 104 & 104 & 1.859 \\
Cytokine & 1 & 103 & 103 & 3.078 \\
Depress. Anxiety & 1 & 100 & 100 & 4.935 \\
Am. J. Geriat. & 1 & 96 & 96 & 3.488 \\
Psychiatr. & 1 & 95 & 95 & 41.037 \\
Science & 1 & 94 & 94 & 10.517 \\
Sleep. Med. Rev. & & & & \\
\hline
\end{tabular}

*Impact factor of 2004.

symptoms. Three studies found the level of pain and depression were decreased after antidepressants therapy, which pointed out the direction of future research in mechanism and treatment of comorbidity of pain and depression.

In present study, most of the top-cited studies reported the comorbidity of pain and depression and indicated that pain and depression have strong and similar effects on one another (Kroenke et al., 2011). Based on the 100 top-cited articles, the presence of pain negatively affects the recognition and treatment of depression, and depression in patients with pain is similarly associated with more pain complaints and greater impairment (Bair et al., 2003, 2008). Higher prevalence of depression was found in patients with moderate or severe chronic pain compared to patients with mild or no pain (34.1 vs. 18.3\%) (Davison and Jhangri, 2005). And a significantly lower Mental Composite Score t-score was found in chronic pain patients with major depressive disorder had than those with minor or no depression (Elliott et al., 2003). Pain and depression are interrelated and interacted. Lin et al. (2003) found benefits of improved depression care extended beyond reduced depressive symptoms and included decreased pain as well as improved functional status and quality of life. Optimized antidepressant therapy followed by a pain self-management program resulted in substantial improvement in depression as well as moderate reductions in pain severity (Kroenke et al., 2009). Cairns et al. (1996) pointed that changes in pain affected depression more than changes in depression affected pain. A 12-month longitudinal analysis in comorbidity of pain and depression also found that change in pain and depression severity was strong predictor of each other (Kroenke et al., 2011).

Pain and depression might share the same biological pathways and neurotransmitters, indicating the same treatment strategy of both concurrently. These mechanisms include direct effects of cytokines on the neuronal environment or indirect effects via downregulation of $\mathrm{G}$ protein-coupled receptor kinase 2, activation of the tryptophan-degrading enzyme indoleamine 2,3dioxygenase that generates neurotropic kynurenine metabolites, increased brain extracellular gluta-mate, and the switch of GABAergic neurotransmission from inhibition to excitation (Romano and Turner, 1985; Bair et al., 2003; Kim et al., 2012). The mesolimbic dopaminergic system (DA) is also shown to associate with both symptoms of pain and depression. Endogenous opioids have been shown to functionally interact 
with DA, and are directly implicated in pain processing and depression symptoms in regions with heavy DAergic innervation (Finan and Smith, 2013). Among these mechanisms, one possible way was the brain indoleamine 2,3-dioxygenase 1-mediated regulatory mechanism, which has been suggested as a new strategy for the treatment of both conditions (Kim et al., 2012). In addition, studies showed that pain and depression are parallel and independent. In patients with fibromyalgia, neither the extent of depression nor the presence of comorbid major depression modulates the sensory-discriminative aspects of pain processing, as measured by sensory testing or fMRI. The sensory and affective elements were independent of one another and respond differentially to both pharmacologic and non-pharmacologic interventions (Giesecke et al., 2005).

There are several limitations to our review work. Firstly, there may be the missing number of citations since the citation analysis only based on the Web of Science. Some databases, like Google and Scopus, are not included in the statistical collection of cited frequency in Web of Science. Secondly, we searched the database based on the contents of titles, and some studies which did not contain the keywords in their titles may be missed for inclusion. Thirdly, we used total citations as the measurement of impact, but as times goes by, the older the articles are the more citations they may receive. So, the list of top-cited articles may be dominated by some old articles. Fourthly, since the 100 top-cited articles were published before 2015, the results of relationship between pain and depression may not be the latest discovery.

\section{REFERENCES}

Arnow, B. A., Hunkeler, E. M., Blasey, C. M., Lee, J., Constantino, M. J., Fireman, B., et al. (2006). Comorbid depression, chronic pain, and disability in primary care. Psychosom. Med. 68, 262-268. doi: 10.1097/01.psy.0000204851.15499.fc

Azer, S. A., and Azer, S. (2016). Bibliometric analysis of the topcited gastroenterology and hepatology articles. BMJ Open 6:e009889. doi: 10.1136/bmjopen-2015-009889

Azoulay, P., Fons-Rosen, C., and Zivin, J. S. G. (2019). Does science advance one funeral at a time? Am. Econ. Rev. 109, 2889-2920. doi: 10.1257/aer.20161574

Bair, M. J., Robinson, R. L., Katon, W., and Kroenke, K. (2003). Depression and pain comorbidity: a literature review. Arch. Intern. Med. 163, 2433-2445. doi: 10.1001/archinte.163.20.2433

Bair, M. J., Wu, J., Damush, T. M., Sutherland, J. M., and Kroenke, K. (2008). Association of depression and anxiety alone and in combination with chronic musculoskeletal pain in primary care patients. Psychosom. Med. 70, 890-897. doi: 10.1097/PSY.0b013e318185c510

Blakeman, K. (2018). Bibliometrics in a digital age: help or hindrance. Sci. Prog. 101, 293-310. doi: 10.3184/003685018X15337564592469

Blyth, F. M., March, L. M., Brnabic, A. J., Jorm, L. R., Williamson, M., and Cousins, M. J. (2001). Chronic pain in Australia: a prevalence study. Pain 89, 127-134. doi: 10.1016/s0304-3959(00)00355-9

Brown, T., Ho, Y. S., and Gutman, S. A. (2019). High impact and highly cited peer-reviewed journal article publications by canadian occupational therapy authors: a bibliometric analysis. Occup. Ther. Health Care 27, 1-26. doi: 10.1080/07380577.2019.1633587

Cairns, D. M., Adkins, R. H., and Scott, M. D. (1996). Pain and depression in acute traumatic spinal cord injury: origins of chronic problematic pain? Arch. Phys. Med. Rehabil. 77, 329-335. doi: 10.1016/s0003-9993(96)90079-9

Campbell, L. C., Clauw, D. J., and Keefe, F. J. (2003). Persistent pain and depression: a biopsychosocial perspective. Biol. Psychiatry 54, 399-409. doi: 10.1016/s0006-3223(03)00545-6
To the best of our knowledge, this study is the first review of top-cited studies in pain and depression. Despite the limitations, we provided evidence of the status and progress in the research field of pain and depression based on the 100 top-cited articles by identifying the contributions made by authors, institutions, and journals. Given the high prevalence of pain and depression, the mechanisms and treatment of the comorbidity of both symptoms remains a key research field.

\section{AUTHOR CONTRIBUTIONS}

YZ and LD designed the study and analyzed the data. SL, GL, HW, YZ, and LZ drafted of the manuscript. All authors approved the final version of the manuscript.

\section{FUNDING}

This study was partly supported by National Clinical Research Center for Geriatrics, West China Hospital, Sichuan University (Z2018B16).

\section{SUPPLEMENTARY MATERIAL}

The Supplementary Material for this article can be found online at: https://www.frontiersin.org/articles/10.3389/fpsyg. 2019.03072/full\#supplementary-material

Chopra, K., and Arora, V. (2014). An intricate relationship between pain and depression: clinical correlates, coactivation factors and therapeutic targets. Expert Opin. Ther. Targets 18, 159-176. doi: 10.1517/14728222.2014.855720

Davison, S. N., and Jhangri, G. S. (2005). The impact of chronic pain on depression, sleep, and the desire to withdraw from dialysis in hemodialysis patients. J. Pain Symptom Manage. 30, 465-473. doi: 10.1016/j.jpainsymman.2005.05.013

Elliott, T. E., Renier, C. M., and Palcher, J. A. (2003). Chronic pain, depression, and quality of life: correlations and predictive value of the SF-36. Pain Med. 4, 331-339. doi: 10.1111/j.1526-4637.2003.03040.x

Finan, P. H., and Smith, M. T. (2013). The comorbidity of insomnia, chronic pain, and depression: dopamine as a putative mechanism. Sleep Med. Rev. 17, 173-183. doi: 10.1016/j.smrv.2012.03.003

Fishbain, D. A., Cutler, R., Rosomoff, H. L., and Rosomoff, R. S. (1997). Chronic pain-associated depression: antecedent or consequence of chronic pain? A review. Clin J Pain 13, 116-137. doi: 10.1097/00002508-199706000-00006

Gagliese, L., Gauthier, L. R., and Rodin, G. (2007). Cancer pain and depression: a systematic review of age-related patterns. Pain Res Manage. 12, 205-211. doi: $10.1155 / 2007 / 150126$

Giesecke, T., Gracely, R. H., Williams, D. A., Geisser, M. E., Petzke, F. W., Clauw, D. J. (2005). The relationship between depression, clinical pain, and experimental pain in a chronic pain cohort. Arthritis Rheum. 52, 1577-1584. doi: 10.1002/art.21008

Gureje, O., Von Korff, M., Simon, G. E., and Gater, R. (1998). Persistent pain and well-being: a World Health Organization Study in Primary Care. JAMA 280, 147-151. doi: 10.1001/jama.280.2.147

Ipekci, T., Yuksel, M., and Tunckiran, A. (2017). Top cited articles in urology from Turkey. Turkish J. Urol. 43, 62-67. doi: 10.5152/tud.2016.98958

Iyengar, R., Wang, Y., Chow, J., and Charney, D. S. (2009). An integrated approach to evaluate faculty members' research performance. Acad. Med. 84, 1610-1616. doi: 10.1097/ACM.0b013e3181bb2364

Kanter, S. L. (2009). Understanding the Journal's Impact. Acad. Med. 84, 1169-70. doi: 10.1097/ACM.0b013e3181b7ffa6 
Katon, W., and Schulberg, H. (1992). Epidemiology of depression in primary care. Gen. Hosp. Psychiatry 14, 237-47. doi: 10.1016/0163-8343(92)90094-q

Kim, H., Chen, L., Lim, G., Sung, B., Wang, S., McCabe, M. F., et al. (2012). Brain indoleamine 2,3-dioxygenase contributes to the comorbidity of pain and depression. J. Clin. Invest. 122, 2940-54. doi: 10.1172/JCI61884

Kroenke, K., Bair, M. J., Damush, T. M., Wu, J., Hoke, S., Sutherland, J., et al. (2009). Optimized antidepressant therapy and pain self-management in primary care patients with depression and musculoskeletal pain: a randomized controlled trial. JAMA 301, 2099-2110. doi: 10.1001/jama.2009.723

Kroenke, K., Theobald, D., Wu, J., Loza, J. K., Carpenter, J. S., Tu, W. (2010). The association of depression and pain with health-related quality of life, disability, and health care use in cancer patients. J. Pain Symptom Manage. 40, 327-41. doi: 10.1016/j.jpainsymman.2009.12.023

Kroenke, K., Wu, J., Bair, M. J., Krebs, E. E., Damush, T. M., Tu, W. (2011). Reciprocal relationship between pain and depression: a 12-month longitudinal analysis in primary care. J. Pain 12, 964-73. doi: 10.1016/j.jpain.2011.03.003

Lepine, J. P., and Briley, M. (2004). The epidemiology of pain in depression. Hum Psychopharmacol. 19(Suppl 1):S3-S7. doi: 10.1002/hup.618

Li, J. X. (2015). Pain and depression comorbidity: a preclinical perspective. Behav. Brain Res. 276, 92-98. doi: 10.1016/j.bbr.2014.04.042

Lin, E. H., Katon, W., Von Korff, M., Tang, L., Williams, J. W. Jr., Kroenke, K., et al. (2003). Effect of improving depression care on pain and functional outcomes among older adults with arthritis: a randomized controlled trial. JAMA 290, 2428-2429. doi: 10.1001/jama.290.18.2428

Miller, L. R., and Cano, A. (2009). Comorbid chronic pain and depression: who is at risk? J. Pain 10, 619-27. doi: 10.1016/j.jpain.2008.12.007

Moed, H. F. (2009). New developments in the use of citation analysis in research evaluation. Arch. Immunol. Ther. Exp. 57, 13-8. doi: 10.1007/s00005-009-0001-5
Romano, J. M., and Turner, J. A. (1985). Chronic pain and depression: does the evidence support a relationship? Psychol. Bull. 97, 18-34. doi: 10.1037/0033-2909.97.1.18

Shuaib, W., Khan, M. S., Shahid, H., Valdes, E. A., and Alweis, R. (2015). Bibliometric analysis of the top 100 cited cardiovascular articles. Am. J. Cardiol. 115, 972-981. doi: 10.1016/j.amjcard.2015.01.029

Smith, B. H., Elliott, A. M., Chambers, W. A., Smith, W. C., Hannaford, P. C., and Penny, K. (2001). The impact of chronic pain in the community. Fam. Pract. 18, 292-299. doi: 10.1093/fampra/18.3.292

WHO (2017). Depression and Other Common Mental Disorders: Global Health Estimates. Available from: Licence: CC BY-NC-SA 3.0 IGO.

Zhang, Y., Quan, L., and Du, L. (2019a). The 100 top-cited studies in cancer immunotherapy. Artif. Cells Nanomed. Biotechnol. 47, 2282-92. doi: 10.1080/21691401.2019.1623234

Zhang, Y., Quan, L., Xiao, B., and Du, L. (2019b). The 100 top-cited studies on vaccine: a bibliometric analysis. Hum. Vaccin. Immunother. 15, 3024-3031. doi: 10.1080/21645515.2019.1614398

Conflict of Interest: The authors declare that the research was conducted in the absence of any commercial or financial relationships that could be construed as a potential conflict of interest.

Copyright $\odot 2020 \mathrm{Du}$, Luo, Liu, Wang, Zheng and Zhang. This is an open-access article distributed under the terms of the Creative Commons Attribution License (CC $B Y)$. The use, distribution or reproduction in other forums is permitted, provided the original author(s) and the copyright owner(s) are credited and that the original publication in this journal is cited, in accordance with accepted academic practice. No use, distribution or reproduction is permitted which does not comply with these terms. 